\title{
PENGARUH IKLIM KOMUNIKASI ORGANISASI TERHADAP KINERJA PEGAWAI KANTOR KELUARGA BERENCANA JAKARTA BARAT
}

\author{
Dede Irawan $^{1} \&$ Antar Venus ${ }^{2}$ \\ ${ }^{1}$ Pemerintah Provinsi DKI Jakarta \\ ${ }^{2}$ Universitas Padjadjaran
}

\begin{abstract}
ABSTRAK
Penelitian ini bertujuan untuk mengetahui besarnya pengaruh iklim komunikasi organisasi yang terdiri dari kepercayaan, partisipasi dalam pembuatan keputusan, kejujuran, keterbukaan komunikasi kepada pegawai, mendengarkan dalam komunikasi dari pegawai dan memperhatikan tujuan kinerja pegawai yang tinggi terhadap kinerja pegawai di Kantor Keluarga Berencana Kota Administrasi Jakarta Barat Penelitian ini menggunakan metode survei eksplanatori yang bertujuan untuk menjelaskan hubungan sebab akibat di antara variabel-variabel penelitian dengan pengujian statistik inferensial analisis jalur. Populasi dalam penelitian ini adalah pegawai Kantor Keluarga Berencana Kota Administrasi Jakarta Barat dengan mengambil seluruh populasi yang ada sebanyak 95 responden. Berdasarkan hasil penelitian menunjukkan bahwa faktor kepercayaan diantara para pegawai, kejujuran di antara para pegawai dan memikirkan tujuan kinerja pegawai yang tinggi mempunyai pengaruh yangsignifikan terhadap kinerja pegawai. Sedangkan faktor partisipasi pegawai dalam pembuatan keputusan, keterbukaan komunikasi kepada pegawai dan mendengarkan dalam komunikasi dari pegawai tidak berpengaruh secara signifikan, namun memberikan komstribusi positif terhadap kinerja pegawai di lingkungan Kantor Keluarga Berencana Kota Administrasi Jakarta Barat. Hasil penelitian ini menunjukkan bahwa pengaruh iklim komunikasi organisasi terhadap kinerja pegawai adalah sebesar 82,1\%, sedangkan sisanya sebesar 17,9\% dipengaruhi oleh variabel lain yang tidak diteliti dalam penelitian ini. Kesimpulan dari penelitian ini adalah terdapat pengaruh iklim komunikasi organisasi baik secara langsung maupun tidak langsung terhadap kinerja pegawai di lingkungan Kantor Keluarga Berencana Kota Administrasi Jakarta Barat.
\end{abstract}

Kata-kata kunci: Kepercayaan, partisipasi dalam pembuatan keputusan, kejujuran, keterbukaan, komunikasi dari pegawai, tujuan kinerja yang tinggi, kinerja pegawai

\section{THE EFFECT OF ORGANIZATIONAL COMMUNICATION CLIMATE TO THE EMPLOYEES PERFORMANCE IN THE FAMILY PLANNING OFFICE OF ADMINISTRATION CITY OF WEST JAKARTA}

\begin{abstract}
The purpose of the study was to see the effect of organizational communication climate, that consist of trust, participation in decision making, honesty, communication openness to the employees, listening to the employees, and attention to the purpose of high employees' performance, to the employees' performance in the family planning office of administration city of West Jakarta. This study used explanatory survei method that aims to explain the causal relationship between the variables of the research with path analysis as its inferential statistical testing. The population of the study was all the employees in the office family planning of city administration of West Jakarta with the total number were 95 respondents. The result of the study showed that the trust among employees, honesty between employees and the thought of high employees'performance goals are significantly influence the employees' performance. While the employees' participation in decision making, communication openness to employees and listening to the employees are not significantly influenced. However, it gives a positive contribution to the employees' performance in the family planning office administration city of Wes Jakarta. Therefore, it is suggested that the organizational communication climate influences the employees'performance about $82,1 \%$, and the remaining about $17,9 \%$ is influenced by other variables that are not examined in this study. The conclusion is that organizational communication climate influences either directly or indirectly to the employees' performance in the family planning office administration city of West Jakarta.

Keywords: Trust, participation in decision making, honesty, communication openness to the employees, goal of high performance, employees' performance
\end{abstract}

Korespondensi: Dede Irawan, S.Pd., M.I.Kom. Pemerintah Provinsi DKI Jakarta. Jalan Medan Merdeka Selatan Jakarta Pusat. Email: irawandede72@gmail.com 


\section{PENDAHULUAN}

Organisasi umumnya terdiri dari unit-unit komunikasi yang berkaitan dengan hubungan hirarkis antara unit yang satu dengan unit lainnya. Seperti apa yang diungkapkan oleh Schein dalam Muhammad (Muhammad, 2011: 23) bahwa:

"Organisasi adalah suatu kordinasi rasional kegiatan sejumlahoranguntukmencapaibeberapa tujuan umum melalui pembagian pekerjaan dan fungsi melalui hirarki otoritas dan tanggung jawab. Selain itu Schein juga mengungkapkan bahwa organisasi mempunyai karakteristik tertentu yang mempunyai struktur, tujuan, saling berhubungan dengan satu bagian dengan bagian lainnya dan sangat tergantung kepada komunikasi manusia untuk mengkordinasikan aktivitas dalam organisasinya".

Setiap unit kerja atau organisasi melakukan berbagai aktivitas untuk mencapai tujuan yang telah ditetapkan sebelumnya yaitu berusaha untuk mendapatkan keuntungan, namun yang lebih utama yaitu mensejahterakan dan memajukan kemampuan pegawainya, karena pegawai merupakan aset bagi unit kerja, dan salah satu aktivitas unit kerja untuk memajukan kemampuan pegawainya. Unit kerja yang berusaha untuk menumbuhkan kepuasan kerja yang tinggi akan mengatur hak dan kewajiban pegawai sedemikian rupa selaras dengan fungsi, peran dan tanggung jawab pegawai sehingga pegawai dapat berpartisipasi dengan baik dalam unit kerja.

Kantor Keluarga Berencana Kota Administasi Jakarta Barat merupakan salah satu organisasi Pemerintah Provinsi Daerah Khusus Ibukota (DKI) Jakarta yang lebih dikenal dengan Unit Kerja Perangkat Daerah (UKPD) yang berada di bawah Badan Pemberdayaan Masyarakat, Perempuan dan Keluarga Berencana (BPMPKB) Provinsi DKI Jakarta, sebagai Satuan Kerja Perangkat Daerah (SKPD), berdasarkan Peraturan Gubernur Nomor 120 Tahun 2009.

Sejak bergulirnya era otonomi daerah, Kantor Keluarga Berencana awalnya ada dibawah naungan Badan Kordinasi Keluarga Berencana Nasional (BKKBN) kemudian dileburdibawahnaunganPemerintah Provinsi DKI Jakarta, banyak mengalami pasang surut baik dari aspek kepemimpinannya maupun dari aspek kinerjanya. Hal ini terjadi karena proses penyesuaian kelembagaan di bawah organisasi induk yang baru berdasarkan Peraturan Daerah Nomor 10 Tahun 2008.

Beberapa kali kantor Keluarga Berencana menginduk kepada instansi lain atau Satuan Kerja Perangkat Daerah (SKPD) lain yang berada di bawah Pemerintah Provinsi DKI Jakarta, hingga akhirnya menginduk kepada Badan Pemberdayaan Masyarakat, Perempuan dan Keluarga Berencana (BPMPKB) sampai saat ini, Kondisi yang ada pada saat itu juga mempengaruhi internal organisasi terlebih bagi pegawainya, di mana para pegawai bekerja dalam kondisi tidak menentu, baik dari aspek jabatan, maupun suasana di lingkungan kerja. Di lain pihak para pegawainya dari waktu ke waktu semakin menyusut atau berkurang hal ini disebabkan banyak pagawai yang mengajukan mutasi ke istansi lain selain para pegawai yang memasuki masa purna bakti atau pensiun. Jumlah pegawai yang awal mulanya berjumlah 165 orang sampai sekarang menyusut menjadi sebanyak 95 orang.

Berdasarkan data laporan tahunan Kantor Keluarga Berenccana Kota Adminstrasi Jakarta Barat pencapaian target peserta KB baru di wilayah Jakarta Barat selalu meningkat setiap tahunnya, namun di sisi lain pencapian peserta KB aktif justru menurun. Hal ini juga membawa dampak naiknya angka Total Fertility Rate (TFR) dari 2,1 menjadi 2,3 yang berarti bahwa setiap ibu Pasangan Usia Subur ratarata memiliki 2, 3 anak. Hal ini menunjukkan bahwa pencapaian TFR yang ditargetkan oleh pemerintah sebesar 1,9 menjadi tidak tercapai.

Keberhasilan komunikasi dalam organisasi merupakan alat perekat hubungan antara sesama anggota organisasi. Untuk meningkatkan kinerja organisasi, semestinya harus didukung dengan iklim komunikasi yang kondusif yang memungkinkan adanya interaksi yang baik antara bawahan dan atasan dan antar sesama bawahan, sehingga memungkinkan semua anggota organisasi melaksanakan tugas dan fungsinya yang sesuai dengan yang digariskan organisasi. Keberhasilan suatu organisasi atau unit kerja dalam mencapai tujuan organisasi sangat tergantung pada faktor sumber daya manusia. Pegawai merupakan sumber daya dalam unit kerja yang perlu mendapat perhatian serius dari tempat mereka bekerja. 
Iklim komunikasi dapat menjadi salah satu pengaruhyang penting dalam produktivitas suatu organisasi, karena iklim dapat mempengaruhi pegawai melalui aktivitas, pelaksanaan tugas kualitas dari hasil dan pola kerja dari suatu unit kerja. Peningkatan kinerja dapat berlangsung apabila karyawan memperoleh informasi yang diperlukan untuk mengerjakan pekerjaan agar sesuai dengan peran karyawan secara tepat terhadap sistem secara keseluruhan yang berlaku dalam organisasi.

Iklim komunikasi merupakan persepsipersepsi tentang unsur-unsur organisasi dan pengaruh unsur-unsur tersebut terhadap organisasi. Iklim komunikasi dapat menjadi salah satu pengaruh yang paling penting dalam produktivitas organisasi. (Pace \& Faules, 2010: 155). Selain itu ia menyatakan bahwa:

"bila sebuah organisasi melakukan suatu rencana intensif keuangan baru atau berperan serta dalam pembuatan, keputusan, mungkin muncul suatu perubahan dalam iklim organisasi. Perubahan pada iklim itu mungkin pada gilirannya mempengaruhi kinerja dan produktivitas pegawai. Peterson dan Pace mengemukakan enam dimensi dari iklim komunikasi yaitu kepercayaan, pembuatan keputusan bersama, kejujuran, keterbukaan dalam komunikasi ke bawah, mendengarkan dalam komunikasi ke atas dan perhatian pada tujuan-tujuan berkinerja tinggi. Kepercayaan mengandung unsur hubungan yang menyangkut kepercayaan, keyakinan dan kredibilitas yang didukung oleh pernyataan dan tindakan. Pembuatan keputusan bersama menyangkut kesempatan untuk berkomunikasi dan berkonsultasi dengan manajemen di atasnya agar dapat berperan serta dalam pembuatan keputusan dan penentuan tujuan. Kejujuran menyangkut kejujuran dan keterusterangan yang mewarnai hubungan dalam organisasi. Keterbukaan dalam komunikasi ke bawah menyangkut adannya kemudahan memperoleh informasi yang berhubungan dengan tugas-tugasnya yang memungkinkan untuk mengkordinasikan pekerjaan dengan bagian-bagian lain. Mendengarkan dalam komunikasi ke atas mengandung pemahaman bahwa personil pada semua tingkatan harus mendengarkan saran dan laporan dari tingkat bawah. Perhatian pada tujuan yang berkinerja tinggi menyangkut komitmen untuk melaksanakan tugas dengan kualitas dan produktivitas tinggi serta perhatian besar terhadap anggota organisasi lainnya."

Realitanya komunikasi sering disepelekan baik oleh unit kerja dan juga individu (pegawai) sebagai ujung tombak dari tujuan organisasi. Komunikasi yang tidak efektif sering kali terjadi antar pegawai karena masalah pribadi atau bahkan masalah internal unit kerja yang disebabkan oleh adanya persaingan antar rekan kerja, selain itu aspek iklim komunikasi dalam organisasi merupakan salah satu yang memiliki pengaruh penting bagi pencapaian kinerja organisasi, karena iklim itu sendiri mempengaruhi para anggota organiasi. Seperti yang diungkapkan Redding bahwa iklim komunikasi lebih luas dari persepsi karyawan terhadap kualitas hubungan dan komunikasi dalam organisasi serta tingkat pengaruh dan keterlibatan (Muhammad, 2011: 85). Pendapat di atas dapat dimaknai bahwa iklim komunikasi tidak hanya menyangkut persepsi-persepsi para anggota tentang hubungan dan komunikasi dalam organisasi tetapi juga sangat besar pengaruhnya dan keterlibatan anggota terhadap pencapian tujuan organisasi.

Arus komunikasi yang kurang baik di dalam unit kerja atau sistem menjadi salah satu penyebab terjadinya komunikasi yang tidak efektif. Ketidakefektifan dalam komunikasi seringkali ditimbulkan oleh masalah individu yang berakibat pada masalah unit kerja. Iklim komunikasi yang baik menjadi salah satu yang diharapkan oleh pegawai untuk meminimalisasi masalah individu dan mampu menciptakan hubungan yang akrab antar pegawai, yang pada akhirnya membantu dalam pemenuhan kebutuhan sosial sehingga dapat mencapai tingkat kepuasan kerja pegawai yang pada gilirannya dapat meningkatkan pencapaian kinerja yang optimal.

Sebagaimana yang dinyatakan Ambraw (2009) bahwa hubungan antara komunikasi dengan kinerja organisasi secara sederhana dapat dideskripsikan yaitu dengan melakukan komunikasi yang efektif sehingga dapat meningkatkan kinerja organisasi.

Oleh karena itu penting untuk diteliti 
seberapa besar pengaruh iklim komunikasi terhadap kinerja pegawai Kantor Keluarga Berencana sehingga diharapkan dengan meningkatkannya kinerja maka akan berdampak kepada pelayanan yang lebih baik kepada masyarakat dan terhadap tujuan organisasi sehingga dapat menciptakan image yang positif bagi Pemerintah Daerah Provinsi DKI Jakarta, khususnya Kantor Keluarga Berencana Kota Administrasi Jakarta Barat.

Dengan demikian, hasil dari penelitian ini diharapkan dapat memberikan masukan kepada perangkat kantor Keluarga Berencana Kota Administrasi Jakarta Barat tentang strategi peningkatan kinerja pegawai melalui iklim komunikasi organisasi yang ada di kantor tersebut. Adapun kontribusi yang dihasilkan berupa evaluasi mengenai kinerja pegawai Kantor Keluarga Berencana dan pengaruh iklim komunikasi oeganisasi terhadap kinerja pegawai kantor tersebut.

Teori input-proses-hasil dikembangkan oleh Barry Collins dan Harold Guetzkow pada tahun 1964, dimana model ini menjelaskan gagasan mengenai pengambilan keputusan di dalam kelompok kerja. Teori dalam tataran tradisi sibernetik ini, dimana pengaruh dan informasi datang kepada kelompok (input), kemudian kelompok mengolah informasi sebagai (proses), dan hasilnya berputar kembali untuk mempengaruhi orang lain (output), sehingga model ini dinamakan model input proses output.

Model yang dikemukakan Barry Collins dan Harold Guetzkow menggambarkan bahwa suatu kelompok kerja (task group) berhadapan dengan dua jenis rintangan atau hambatan sebagai faktor masukan yaitu rintangan kerja (task obstacles) dan rintangan antarpersonal (interpersonal obstacles) (Littlejohn \& Foss, 2009: 331). Rintangan kerja adalah kesulitan-kesulitan yang ditemui dalam kelompok di dalam melaksanakan tugas seperti perencanaan dalam pekerjaan, persetujuan mengenai kebijakan-kebijakan, saran-saran yang diperlukan dalam pemecahan masalah, dan alternatif-alternatif yang diambil dalam pengambilan keputusan. Sedangkan rintangan atau hambatan antarpersonal meliputi kebutuhan untuk membuat gagasan atau ide yang dapat dengan jelas dipahami oleh anggota kelompok, menyikapi berbagai masalah, kebutuhan untuk mengatasi konflik, mengatur perbedaan dan sebagainya yang berhubungan dengan komunikasi secara interpersonal. Dengan demikian setiap kelompok kerja dan anggotanya harus secara serempak mengatasi hambatan tugas dan hambatan interpersonal.

Kedua jenis perilaku ini merupakan unsur penting dalam peningkatan produktivitas kelompok dan setiap analisis yang dilakukan di dalam membahas masalah kelompok harus membahas kedua unsur tersebut. Jika perilaku kerja dan perilaku antarpersonal ini dipadukan secara efektif, maka akan dihasilkan efek gabungan, yaitu suatu hasil kerja atau produk yang lebih baik dari pada hasil masing-masing individu (Morissan, 2013: 346).

Penghargaan kelompok memungkinkan adanya hasil yang positif maupun negatif, sebagai dampak dari tugas pekerjaan ataupun interpersonal. Tugas suatu kelompok kerja yang berhasil dilaksanakan merupakan suatu bentuk penghargaan terhadap pekerjaan atau disebut task reward dan kesenangan atau kepuasan yang dirasakan setelah berhasil melaksanakan tugas merupakan penghargaan interpersonal (interpersonal reward), sehingga jika tugas yang dapat diselesaikan dengan baik di dalam kelompok kerja maka hal ini akan membuka peluang untuk membentuk kelompok kerja di masa mendatang. Namun apabila tidak dapat mengatasi perbedaan-perbedaan yang ada, kerjasama di masa mendatang akan sulit dilakukan.

Upaya-upaya yang dilakukan oleh kelompok dalam menghadapi hambatan kerja dan hambatan interpersonal untuk mencapai tujuan sebagai suatu energi. Energi itu sebagian untuk menghadapi hambatan interpersonal dan sebagian lagi untuk mengatasi hambatan kerja. Jumlah energi yang digunakan untuk mengatasi hambatan interpersonal di sebut sebagai sinergi intrinsik dan sisa dari energi yang digunakan untuk mengatasi hambatan kerja disebut sebagai sinergi efektif. Oleh karena itu apabila sinergi efektif tinggi, maka tugas dapat dilaksanakan dengan efektif pula atau dengan kata lain dapat dilaksanakan dengan baik.

Tingkat sinergi dalam suatu kelompok merupakan hasil dari sikap anggota kepada anggota lainnya. Apabila ada hamabatan berupa konflik akan mengambil energi yang besar untuk mempertahankan kelompok 
sehingga sedikit energi untuk menyelesaikan tugas, sebaliknya apabila adanya kesamaan sikap diantara anggota akan membutuhkan energi interpersonal yang sedikit, sehingga sinergi efektif untuk menyelesaikan tugas cukup besar.

Dari gambaran teori masukan-proses dan hasil di atas dapat dipahami bahwa iklim komunikasi organisasi menyangkut sinergi efektif, karena berhubungan dengan perilaku yang terkait dengan lingkungan pekerjaan seperti pamahaman atau persepsi-persepsi mengenai kebijakan pelaksanaan tugas dalam organisasi Sinergi efektif ini berkaitan dengan energi yang dibutuhkan untuk menghadapi hambatanhambatan kerja. Selain itu juga merupakan perilaku yang berkaitan dengan pengaruh interpersonal yang didalamnya berhubungan dengan pembuatan gagasan atau ide, kebutuhan untuk mengelola dan mengatasi konflik dan perbedaan di antara anggota organisasi. Sinergi intrinsik dibutuhkan untuk menghadapi hambatan komunikasi di antara anggota dalam organisasi.

Apabila energi interpersonal yang berkaitan dengan pengelolaan hubungan-hubungan antar anggota yang dibutuhkan cukup sedikit, maka energi efektif untuk mengelola pesan-pesan yang berkaitan dengan tugas akan cukup besar sehingga produktifitas kerja atau hasil kerja yang dicapai akan semakin baik (efektif), dalam artian bahwa apabila iklim komunikasi organisasi yang di bangun semakin baik akan menciptakan hasil kerja yang semakin baik pula. Oleh karena itu iklim komunikasi sebagai suatu bagian dari perilaku-perilaku yang ada dalam organisasi sangat membawa pengaruh besar bagi pencapaian hasil kerja atau kinerja organisasi.

Iklim komunikasi merupakan suatu kiasan dalam bentuk ucapan yang di dalamnya mengandung suatu istilah yang jelas, untuk diterapkan pada situasi yang berbeda dengan tujuan menyatakan suatu kemiripan. Seperti yang dikemukakan Sackmann (Pace \& Faules, 2010, 147) yang menyatakan bahwa:

"suatu kiasan dapat memberi gambaran yang gamblang pata tingkat kognitif, emosional, perilaku dan menyatakan suatu bagian tertentu pada tindakan tanpa menetapkan perilaku sebenarnya". Iklim komunikasi merupakan gabungan dari persepsi-persepsi, suatu evaluasi makro mengenai peristiwa komunikasi, perilaku, respons dari anggota organisasi terhadap yang lainnya, harapan-harapan, konflik antar pribadi dan kesempatan bagi pertumbuhan dalam organisasi tersebut. Sehingga iklim komunikasi berbeda dengan dengan iklim organisasi dalam arti iklim komunikasi meliputi persepsipersepsi mengenai pesan dan peristiwa yang berhubungan dengan pesan yang terjadi di dalam organisasi (Pace \& Faules, 2010: 147).

Berdasarkan penelitian yang dilakukan Pace dan Faules, ada enam faktor yang mempengaruhi iklim komunikasi dalam organisasi, yaitu: Kepercayaan; setiap pegawai pada semua tingkatan harus mampu mengembangkan dan memelihara hubungan saling percaya, kepercayaan pada diri sendiri serta kredibilitas tinggi yang diwujudkan melalui pernyataan maupun tindakan. Pengambilan keputusan yang partisipatif; setiap pegawai harus saling berkomunikasi adan berkonsultasi atas semua isu yang ada di lingkungan organisasi menyangkut kebijakan organisasi yang releven dengan tugas mereka.

Para pegawai di semua tingkatan harus diberi jalan untuk berkomunikasi dan berkonsultasi dengan pimpinannya agar mereka dapat berpartisipasi dalam pengambilan keputusan. Kejujuran; suasana umum yang diliputi kejujuran dan keterusterangan harus mewarnai hubungan-hubungan dalam organisasi dimana para pegawai secara terbuka mampu mengatakan apa yang ada dalam pikiran mereka, tanpa mengindahkan dan melihat dengan siapa mereka berbicara. Keterbukaan di dalam komunikasi ke bawah; para pegawai harus memilki kemudahan memperoleh informasi, terutama informasi yang berhubungan langsung dengan tugas-tugasnya, yang mempengaruhi kemampuan mereka untuk berkordinasi dengan bagian-bagian lain dan informasi yang berhubungan dengan organisasi itu sendiri. Mendengarkan di dalam komunikasi ke atas; setiap pegawai pada semua tingkatan harus saling mendengarkan secara kontinyu dengan pikiran terbuka tentang saran atau laporan masalah yang datang dari pegawai di bawahnya, informasi yang datang dari bawah harus serius untuk diperhatikan dan ditindak lanjuti. Perhatian 
pada tujuan berkinerja tinggi; setiap pegawai pada semua tingkatan harus memiliki komitmen untuk mencapai tujuan-tujuan berkinerja tinggi; produktivitas dan kualitas tinggi dengan biaya rendah.

Kinerja seseorang merupakan kombinasi dari kemampuan, usaha dan kesempatan yang dapat dinilai dari hasil kerjanya. menurut Sutrisno (2004: 170) kinerja adalah hasil kerja yang dapat dicapai oleh seseorang atau sekelompok orang dalam suatu organisasi, sesuai dengan wewenang dan tanggung jawab masing-masing, dalam rangka upaya mencapai tujuan organisasi bersangkutan secara legal, tidak melanggar hukum, dan sesuai dengan moral dan etika. Sedangkan pengertian kinerja menurut Mahsun (2006: 25) adalah gambaran mengenai pencapaian pelaksanaan suatu kegiatan dalam mewujudkan sasaran, tujuan, misi dan visi organisasi yang tertuang dalam strategic planning suatu organisasi.

Pengertian lain tentang kinerja menurut Milner (1990) dalam bukunya Sutrisno (2004: 170) adalah bagaimana seseorang di harapkan dapat berfungsi dan berperilaku sesuai dengan tugas yang telah dibebankan kepadanya. Setiap harapan mengenai bagaimana seseorang harus berperilaku dalam melaksanakan tugas, berarti menunjukan suatu peran dalam organisasi. Keberhasilan organisasi tergantung pada kinerja para pelaku organisasi bersangkutan. Oleh karenaitu, setiap unitkerja dalam suatu organisasi harus dinilai kinerjanya agar kinerja sumberdaya manusia yang terdapat dalam unit-unit dalam suatu organisasi dapat dinilai secara objektif. Pada prinsipnya kinerja uni-unit organisasi dimana seseorang atau sekelompok orang berada di dalamnya merupakan pencerminan dari kinerja sumber daya manusia yang bersangkutan.

Bernardin dan Russel dalam Sutrisno (2009: 179-180), mengajukan enam poin penilaian kinerja yaitu: Quality (kualitas kerja); merupakan tingkat sejauh mana proses atau hasil pelaksanaan kegiatan mendekati kesempurnaan atau mendekati tujuan yang diharapkan. Quantity (kuantitas kerja); merupakan jumlah yang dihasilkan misalnya siklus kegiatan yang dilakukan. Timeliness (ketepatan waktu); merupakan sejauh mana suatu kegiatan diselesaikan pada waktu yang tepat yang dikehendaki, dengan memerhatikan kordinasi output lain serta waktu yang tersedia untuk kegiatan orang lain. Cost efectiveness (efektivitas biaya); merupakan tingkat sejauh mana penggunaan sumber daya organisai (manusia, keuangan, teknologi, dan material) dimaksimalkan untuk mencapai hasil tertinggi atau pengurangan kerugian dari setiap unit penggunaan sumber daya. Need for supervisior (perluuntukpengawasan); merupakantingkatsejauh mana seorang pekerja dapat melaksanakan suatu fungsi pekerjaan tanpa memerlukan pengawasan seorang supervisior untuk mencegah tindakan yang tidak diinginkan. Interpersonal impact; merupakan tingkatan sejauh mana pegawai memelihara harga diri, nama baik, dan kerja sama di antara rekan kerja dan bawahan.

\section{METODE PENELITIAN}

Penelitian ini menggunkan pendekatan kuantitatif dengan metode penelitian yang digunakan dalam penelitian ini adalah metode survei, yaitu metode penelitian yang mengambil sampel dari suatu populasi dengan menggunakan kuesioner sebagai alat pengumpulan data yang pokok (Singarimbun \& Effendi, 1995: 3). Tujuannya adalah untuk memperoleh informasi tentang sejumlah responden yang dianggap mewakili populasi tertentu.

Responden (sampel) diasumsikan mewakili populasi secara spesifik. Jenis metode survei yang digunakan adalah eksplanatori yang bertujuan untuk memperoleh penjelasan tentang hubungan sebab akibat diantara variabel-variabel penelitian dan pengujian hipotesis dilakukan dengan bantuan statistik sehingga dengan cara demikian akan dapat ditarik kesimpulan makna dari data yang diperoleh. Untuk menguji hipotesis digunakan statistik inferensial dan dari uji hipotesis tersebut diharapkan dapat disimpulkan beberapa fenomena yang terjadi berdasarkan pengolahan dan analisis data.

Populasi merupakan seluruh subjek yang akan diteliti, seperti yang dikemukakan oleh Arikunto yaitu: "populasi adalah keseluruhan subyek penelitian" (Arikunto, 2002: 108). Populasi dalam penelitian ini adalah meliputi seluruh pegawai Kantor Keluarga Berencana Kota Administrasi Jakarta Barat, dan menurut data pada kantor tersebut total pegawai yang ada pada saat ini adalah berjumlah 95 orang. Dalam hal ini sumber data yang diambil adalah 
data dari seluruh populasi yang ada yaitu sebanyak 95 responden. Hal ini dimungkinkan karena populasi yang ada tidak terlalu banyak dan dapat dijangkau oleh peneliti.

Analisis dalam penelitian inimenggunakan analisis deskriptif yang bertujuan untuk memberikan gambaran data responden yang ditunjukkan dengan tabel tunggal yang bertujuan untuk menyederhanakan data ke dalam bentuk yang mudah dibaca dan diinterpretasikan, serta analisis tatistik inferensial digunakan untuk penelitian eksplanatory yang menjelaskan hubungan dua variabel atau lebih. Untuk pengujiannya digunakan analisis jalur (Path Analysis) yang dikembangkan oleh Sewall Wright. Model ini digunakan untuk mengetahui seberapa besar pangaruh langsung atau tidak langsung/ secara bersama sautu variabel terhadap variabel lainnya. Berdasarkan rancangan penelitian yang telah diuraikan sebelumnya, maka gambaran struktur variabel penelitian dapat dilihat pada Gambar 1.

\section{HASIL DAN PEMBAHASAN}

Pengaruh total kepercayaan, partisipasi dalam pembuatan keputusan, kejujuran, keterbukaan komunikasi kepada pegawai, mendengarkan dalam komunikasi dari pegawai, dan memikirkan tujuan kinerja pegawai yang tinggi (iklim komunikasi organisasi) terhadap kinerja pegawai terdiri dari pengaruh langsung dan pengaruh tidak langsung, hasilnya diuraikan berikut:

- Besarnya pengaruh langsung:

1. X1 terhadap Y (Pyx1) adalah $=0,387^{2}$ $\mathrm{X} 100 \%=15,0 \%$

2. $\mathrm{X} 2$ terhadap $\mathrm{Y}(\mathrm{Pyx} 2)$ adalah $=-0,012^{2}$ $\mathrm{x} 100 \%=0,0 \%$

3. $\mathrm{X} 3$ terhadap $\mathrm{Y}(\mathrm{Pyx} 3)$ adalah $=0,266^{2}$ $\mathrm{x} 100 \%=7,1 \%$

4. $\mathrm{X} 4$ terhadap $\mathrm{Y}(\mathrm{Pyx} 4)$ adalah $=-0,076^{2}$

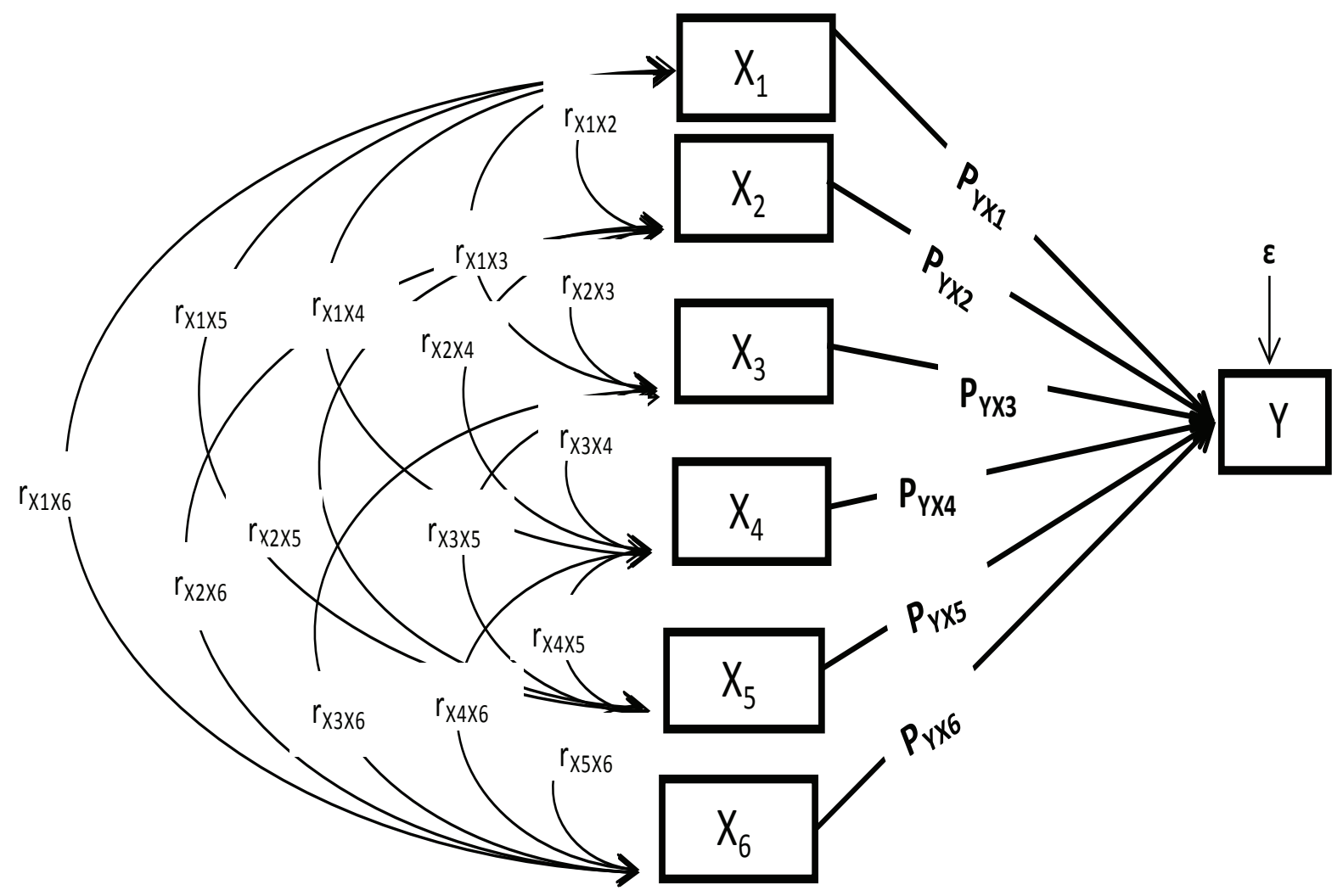

\section{Gambar 1 Diagram Jalur Variabel Penelitian}

\footnotetext{
Keterangan:

$\mathrm{X}_{1} \quad$ : Kepercayaan di antara para pegawai

$\mathrm{X}_{2} \quad$ : Partisipasi pegawai dalam pembuatan keputusan

$\mathrm{X}_{3} \quad$ : Kejujuran para pegawai

$\mathrm{X}_{4} \quad$ : Keterbukaan komunikasi kepada pegawai

$\mathrm{X}_{5} \quad$ : Mendengarkan dalam komunikasi dari pegawai

$\mathrm{X}_{6} \quad$ : Memikirkan tujuan kinerja pegawai yang tinggi

$\mathrm{Y}^{6} \quad$ : Kinerja Pegawai

$\varepsilon \quad$ : Variabel lain yang tidak diukur dalam penelitian ini
} 
$\mathrm{X} 100 \%=0,6 \%$

5. X5 terhadap Y (Pyx5) adalah $=-0,170^{2}$ $\mathrm{X} 100 \%=2,9 \%$

6. X6 terhadap Y (Pyx6) adalah $=0,339^{2}$ $\mathrm{x} 100 \%=11,5 \%$

- Besarnya pengaruh tidak langsung:

1. X1 terhadap $\mathrm{Y}$ melalui $\mathrm{X} 2$ adalah $0,387 \times-0,012 \times 0,306 \times 100 \%=-0,1 \%$

2. $\mathrm{X} 1$ terhadap $\mathrm{Y}$ melalui $\mathrm{X} 3$ adalah $0,387 \times 0,266 \times 0,273 \times 100 \%=2,8 \%$

3. $\mathrm{X} 1$ terhadap $\mathrm{Y}$ melalui $\mathrm{X} 4$ adalah $0,387 \times-0,076 \times 0,110 \times 100 \%=-0,3 \%$

4. X1 terhadap Y melalui X5 adalah 0,387 $\mathrm{x}-0,170 \times 0,102 \times 100 \%=-0,7 \%$

5. X1 terhadap $\mathrm{Y}$ melalui $\mathrm{X} 6$ adalah $0,387 \times 0,339 \times 0,503 \times 100 \%=6,6 \%$

6. X2 terhadap $\mathrm{Y}$ melalui $\mathrm{X} 3$ adalah $-0,012 \times 0,266 \times 0,462 \times 100 \%=-0,1 \%$

7. $\mathrm{X} 2$ terhadap $\mathrm{Y}$ melalui $\mathrm{X} 4$ adalah $-0,012 \times-0,076 \times 0,010 \times 100 \%=0,0 \%$

8. X2 terhadap $\mathrm{Y}$ melalui $\mathrm{X} 5$ adalah $-0,012 \times-0,170 \times 0,365 \times 100 \%=0,1 \%$

9. $\mathrm{X} 2$ terhadap $\mathrm{Y}$ melalui $\mathrm{X} 6$ adalah $-0,012 \times 0,339 \times 0,545 \times 100 \%=-0,2 \%$

10. X3 terhadap $\mathrm{Y}$ melalui $\mathrm{X} 4$ adalah $0,266 \times-0,076 \times 0,150 \times 100 \%=$ $-0,3 \%$

11. X3 terhadap $\mathrm{Y}$ melalui $\mathrm{X} 5$ adalah $0,266 \times-0,170 \times 0,282 \times 100 \%=$ $-1,3 \%$

12. X3 terhadap $\mathrm{Y}$ melalui $\mathrm{X} 6$ adalah $0,266 \times 0,339 \times 0,481 \times 100 \%=4,3 \%$

13. X4 terhadap $\mathrm{Y}$ melalui $\mathrm{X} 5$ adalah

$$
\begin{aligned}
& -0,076 \times-0,170 \times 0,157 \times 100 \%= \\
& 0,2 \%
\end{aligned}
$$

14. X4 terhadap $\mathrm{Y}$ melalui $\mathrm{X} 6$ adalah $-0,076 \times 0,339 \times 0,037 \times 100 \%=$ $-0,1 \%$

15. X5 terhadap $\mathrm{Y}$ melalui $\mathrm{X} 6$ adalah $-0,170 \times 0,339 \times 0,131 \times 100 \%=$ $-0,8 \%$

- Besarnya pengaruh total $X_{1}, X_{2} X_{3}$,

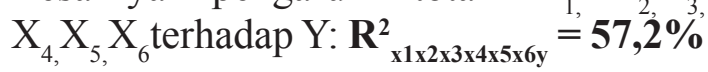

Dari perhitungan di atas dapat disimpulkan besarnya pengaruh baik langsung maupun tidak langsung seperti tercantum pada Tabel 1.

Dari tabel 1 dapat disimpulkan besarnya pengaruh masing-masing faktor adalah:

1. Kepercayaan $\left(X_{1}\right)$ berpengaruh secara langsung dan tidak langsung terhadap kinerja pegawai (Y) sebesar 23,3\%.

2. Partisipasi dalam pembuatan keputusan $\left(\mathrm{X}_{2}\right)$ berpengaruh secara langsung dan tidak langsung terhadap kinerja pegawai (Y) sebesar $-0,4 \%$.

3. Kejujuran $\left(\mathrm{X}_{3}\right)$ berpengaruh secara langsung dan tidak langsung terhadap kinerja pegawai (Y) sebesar $12,5 \%$.

4. Keterbukaan komunikasi kepada pegawai $\left(\mathrm{X}_{4}\right)$ berpengaruh secara langsung dan tidak langsung terhadap kinerja pegawai (Y) sebesar $0,1 \%$.

5. Mendengarkan dalam komunikasi dari pegawai $\left(\mathrm{X}_{5}\right)$ berpengaruh secara langsung dan tidak langsung terhadap

Tabel 1 Pengaruh Langsung dan Tidak Langsung Dimensi-Dimensi Iklim Komunikasi Organisasi

\begin{tabular}{|c|c|c|c|c|c|c|c|c|}
\hline & \multirow{2}{*}{$\begin{array}{l}\text { Pengaruh } \\
\text { Langsung }\end{array}$} & \multicolumn{6}{|c|}{ Pengaruh Tidak Langsung, melalui } & \multirow{2}{*}{ Total } \\
\hline & & $\mathrm{X} 1$ & $\mathrm{X} 2$ & $\mathrm{X} 3$ & $\mathrm{X} 4$ & $\mathrm{X} 5$ & $\mathrm{X} 6$ & \\
\hline $\mathrm{X} 1$ & $15,0 \%$ & - & $-0,1 \%$ & $2,8 \%$ & $-0,3 \%$ & $-0,7 \%$ & $6,6 \%$ & $23,3 \%$ \\
\hline $\mathrm{X} 2$ & $0,0 \%$ & $-0,1 \%$ & - & $-0,1 \%$ & $0,0 \%$ & $0,1 \%$ & $-0,2 \%$ & $-0,4 \%$ \\
\hline $\mathrm{X} 3$ & $7,1 \%$ & $2,8 \%$ & $-0,1 \%$ & - & $-0,3 \%$ & $-1,3 \%$ & $4,3 \%$ & $12,5 \%$ \\
\hline $\mathrm{X} 4$ & $0,6 \%$ & $-0,3 \%$ & $0,0 \%$ & $-0,3 \%$ & - & $0,2 \%$ & $-0,1 \%$ & $0,1 \%$ \\
\hline $\mathrm{X} 5$ & $2,9 \%$ & $-0,7 \%$ & $0,1 \%$ & $-1,3 \%$ & $0,2 \%$ & - & $-0,8 \%$ & $0,5 \%$ \\
\hline \multirow[t]{4}{*}{$\mathrm{X} 6$} & $11,5 \%$ & $6,6 \%$ & $-0,1 \%$ & $4,3 \%$ & $-0,1 \%$ & $-0,8 \%$ & - & $21,4 \%$ \\
\hline & \multicolumn{7}{|c|}{ Pengaruh variabel $\mathrm{X}$ terhadap $\mathrm{Y}$} & $57.2 \%$ \\
\hline & \multicolumn{7}{|c|}{ Pengaruh variabel lain } & $42.8 \%$ \\
\hline & \multicolumn{7}{|c|}{ Total Pengaruh } & $100 \%$ \\
\hline
\end{tabular}
Terhadap Kinerja Pegawai 
kinerja pegawai (Y) sebesar $0,5 \%$.

6. Memikirkan tujuan kinerja pegawai yang tinggi $\left(\mathrm{X}_{6}\right)$ berpengaruh secara langsung dan tidak langsung terhadap kinerja pegawai (Y) sebesar 21,4\%.

Hasil ini menunjukkan bahwa kejujuran $\left(\mathrm{X}_{3}\right)$ dalam penelitian ini memiliki pengaruh paling besar dan signifikan terhadap kinerja pegawai di lingkungan Kantor Keluarga Berencana Kota Jakarta Barat, yang kemudian diikuti oleh memikirkan tujuan kinerja pegawai yang tinggi $(\mathrm{X} 6)$ dan kepercayaan $\left(\mathrm{X}_{1}\right)$.

Berdasarkan data yang diperoleh di lapangan, analisis data serta pengujian terhadap subvariabelyangada, makamenunjukkan bahwa keenam sub variabel dari iklim komunikasi organisasi yang terdiri dari kepercayaan, partisipasi pegawai dalam pembuatankeputusan, kejujuran, keterbukaan komunikasi kepada pegawai, mendengarkan dalam komunikasi dari pegawai dan memikirkan tujuan kinerja pegawai yang tinggi secara bersama-sama memiliki pengaruh yang signifikan terhadap kinerja pegawai di Kantor Keluarga Berencana Kota Administrasi Jakarta Barat.

Uji koefisien jalur secara keseluruhan dapat dilihat dari $F$ hitung sebesar 15,615 dengan nilai $p$ sebesar 0,000 . Hal ini menunjukkan bahwa nilai $\mathrm{p}(0,000)<\alpha(0,05)$ atau $\mathrm{F}$ hitung $(15,615)>\mathrm{F}$ tabel $(2,231)$ maka $\mathrm{H}_{0}$ ditolak $\mathrm{H}_{1}$ diterima artinya kepercayaan, partisipasi dalam pembuatan keputusan, kejujuran, keterbukaan komunikasi kepada pegawai, mendengarkan dalam komunikasi dari pegawai, dan memikirkan tujuan kinerja pegawai yang tinggi (iklim komunikasi organisasi) terhadap kinerja pegawai. Hal ini berarti koefisien jalur benarbenar menunjukkan pengaruh sesuai diagram konseptual yang dihipotesiskan.

Kantor Keluarga Berencana Kota Administrasi Jakarta Barats sebagai suatu bentuk organisasi pemerintah yang berada di bawah naungan Pemerintah propvinsi DKI Jakarta merupakan organisasi yang memiliki struktur yang jelas, yang di atur berdasarkan Peraturan Daerah Nomor 10 Tahun 2008. Sebagai organisasi tentu saja mempunyai manajemen tertentu dalam mencapai tujuannya, di mana di dalamnya akan selalu ada interaksi dengan lingkungan organisasinya, terutama interkasi di antara para pegawai.

Setiap adanya perubahan kepemimpinan maupun rotasi antar pegawai tentu saja akan membawa perubahan terhadapiklim komunikasi organisasi. Dalam era modernitas saat ini organisasi harus mampu untuk beradaptasi terhadap perubahan-perubahan yang ada serta mampu menyesuaikan terhadap tuntutan masyarakat. Perubahan-perubahan yang terjadi sebagai suatu bentuk iklim komunikasi tentunya bermuara kepada peningkatan kinerja dan tujuan organisasi.

Adanya perubahan besar yang dilakukan Pemerintah Provinsi DKI Jakarta di dalam penataan struktur organisasi pada setiap satuan kerja perangkat daerah (SKPD) sejak tiga tahun ke belakang, terutama pada struktur organisasi Badan Pemberdayaan Masyarakat dan Perempuan dan Keluarga Berencana yang menaungi Kantor Keluarga Berencana Kota Administrasi Jakarta Barat melalui Peraturan Gubernur Provinsi DKI Jakarta Nomor 227 Tahun 2014 membawa dampak yang besar terhadap kondisi internal organisasi. Selain itu pula adanya aturan baru yang mengharuskan setiap pegawai memiliki rencana kerja yang secara periodik dievaluasi berdasarkan capaian hasil kerja.

Tuntutan pertumbuhan tatanan organisasi ini membawa pengaruh positif terhadap para pegawai, dimana pegawai dituntut untuk dapat menyesuaikan konsep pelayanan terhadap masayarakat, dari konsep dilayani menjadi melayani. Selain itu para pegawai dituntut untuk bisa lebih memahami pesanpesan yang disampaikan organisasi atau para pimpinan dalam bentuk tugas-tugas yang harus dilaksanakan serta meningkatkan kemampuan interpersonal agar dapat bekerjasama dengan baik antar pegawai sehingga tugas-tugas yang dilaksanakan menghasilkan capaian yang baik pula. Hal ini sesuai dengan yang dikemukakan oleh Redding dan Dennis (Goldhaber, 1993: 65) bahwahal paling mendasardariiklimkomunikasi adalah persepsi kognitif maupun afektif dari individu tentang organisasi mempengaruhi bagaimana individu tersebut berperilaku dalam organisasi. Hal ini juga sejalan dengan pendapat Pace dan Faules (2010: 155) bahwa:

"Iklim komunikasi organisasi dapat menjadi salah satu pengaruh yang paling penting dalam produktivitas organisasi, 
karena iklim mempengaruhi usaha anggota organisasi. Usaha dalam hal ini merujuk kepada penggunaan tubuh secara fisik dalam bentuk mengangkat, berbicara, ataupun berjalan, dam penggunaan pikiran mental dalam bentuk berpikir, menganalisis dan memecahkan masalah".

Perubahan yang terjadi dalam struktur Pemerintah Provinsi DKI Jakarta merupakan bagian dari proses organisasi, dimana perubahan tersebut dimaksudkan agar mampu mengembangkan kemampuan dalam pelayanan kepada masyarakat. Menurut Djatmiko (Torang, 2014: 101) menyebutkan bahwa ada tujuh tujuan perubahan organisasi, yaitu: a) meningkatkan kinerja, b) memperbaiki motivasi, c) meningkatkan kerjasama, d) memperjelas komunikasi, e) mengurangi kemangkiran dan keluarnya pengurus organisasi, f) meminimalkan konflik dan g) mengurangi biaya.

Adaya perubahan-perubahan yang terjadi di lingkungan Pemerintah Provinsi DKI Jakarta itu tentu saja menuntut perubahan mind set para pegawai di lingkungan Kantor Keluarga Berencana Kota Administrasi Jakarta Barat sehingga para pegawai mempunyai motivasi yang tinggi dalam bekerja, mampu meningkatkan kerjasama dengan bagian-bagian lain, meningkatkan kemampuan interpersonal dalam pelaksanaan tugas yang pada ujungnya mampu meningkatkan kinerja pegawainya.

\section{SIMPULAN}

Berdasarkan hasil penelitian ini, secara umum dapat disimpulkan bahwa terdapat pengaruh yang positif dan signifikan iklim komunikasi organisasi terhadap kinerja pegawai Kantor Keluarga Berencana Kota Administrasi Jakarta Barat. Selain itu secara parsial dapat ditarik kesimpulan sebagai berikut: (1) Berdasarkan hasil analisis secara parsial, terdapat pengaruh yang signifikan kepercayaan di antara para pegawai terhadap kinerja pegawai di Kantor Keluarga Berencana Kota Administrasi Jakarta Barat, (2) Berdasarkan hasil analisis secara parsial, tidak terdapat pengaruh yang signifikan partisipasi pegawai dalam pembuatan keputusan terhadap kinerja pegawai di Kantor Keluarga Berencana Kota Administrasi Jakarta Barat, (3) Berdasarkan hasil analisis secara parsial, terdapat pengaruh yang signifikan kejujuran di antara pegawai terhadap kinerja pegawai di Kantor Keluarga Berencana Kota Administrasi Jakarta Barat, (4) Berdasarkan hasil analisis secara parsial tidak terdapat pengaruh yang signifikan keterbukaan komunikasi kepada pegawai terhadap kinerja pegawai di Kantor Keluarga Berencana Kota Administrasi Jakarta Barat, (5) Berdasarkan hasil analisis secara parsial, tidak terdapat pengaruh yang signifikan mendengarkan dalan komunikasi dari pegawai terhadap di Kantor Keluarga Berencana Kota Administrasi Jakarta Barat, dan (6) Beradasarkan hasil analisis secara parsial, terdapat pengaruh yang signifikan memikirkan tujuan jinerja pegawai yang tinggi terhadap kinerja pegawai di Kantor Keluarga Berencana Kota Administrasi Jakarta Barat.

Saran-saranyang dapatdisampaikanadalah berdasarkan dimensi-dimensi yang dijadikan kajian terhadap variabel iklim komunikasi organisasi, terdapat dimensi-dimensi yang tidak berpengaruh secara signifikan terhadap kinerja pegawai di Kantor Keluarga Berencana Kota Administrasi Jakarta Barat, seperti partisipasi pegawai dalam pengambilan keputusan, keterbukaan komunikasi kepada pegawai dan mendengarkan dalam komunikasi dari pegawai harus lebih diperhatikan sebagai masukan bagi instansi, walaupun usaha-usaha ke arah sana sudah ada, perlu adanya peningkatan yang lebih positif ke arah partisipasi pegawai dalam pengambilan keputusan dan keterbukaan komunikasi dari dan kepada pegawai, agar kinerjanya lebih optimal. Dimensi-dimensi lain dalam iklim komunikasi organisasi seperti kepercayaan, kejujuran dan memikirkan tujuan kinerja pegawai yang tinggi yang membawa pengaruh signifikan cukup tinggi terhadap kinerja pegawai di Kantor Keluarga Berencana Kota Administrasi Jakarta Barat hendaknya tetap dipertahankan agar pencapaian kinerja pegawai lebih optimal.

\section{DAFTAR PUSTAKA}

Ambraw H. (2009). Hubungan profil individu, iklim komunikasi organisasi dan perilaku komunikasi aparatur dengan pelaksanaan good governence. Tesis. Bogor. Institut Pertanian Bogor. Diaksesdarihttp://repository.ipb.ac.id/ 
bitstream/handle/123456789/72007/ I14afa1. pdf? sequence

Arikunto, S. (2002). Prosedur penelitian: suatu pendekatan praktis. Jakarta: Rineka Cipta.

Goldhaber, G. M. (1993). Organizational communications. Iowa: Wm. Brown Publisher

Laporan Tahunan Kantor Keluarga Berencana Kota Adaministrasi Jakarta Barat Tahun 2013

Littlejohn, S. W., \& Foss, K. A. (2009). Teori Komunikasi: theories of human commmunication, terjemahan. Jakarta: Salemba Humanika.

Morissan. (2013). Teori komunikasi; individu hingga massa. Jakarta: Kencana

Muhammad,A.(2011). Komunikasiorganisasi. Jakarta: Bumi Aksara.
Pace, R. W., \& Faules, D. F. (2010). Komunikasi organisasi: strategi meningkatkan kinerja perusahaan. Bandung: Rosda Karya.

Peraturan Gubernur Provinsi DKI Jakarta Nomor 120 Tahun 2009 tentang Organisasi dan Tata Kerja Badan Pemberdayaan Masyarakat dan Perempuan dan Keluarga Berencana

Peraturan Daeran Provinsi DKI Jakarta Nomor 10 Tahun 2008 tentang Organisasi dan Perangkat Daerah Provinsi Daerah Khusus Ibukota Jakarta

Singarimbun, M. \& Effendi, S. (1995). Metode penelitian survei. Jakarta: LP3S

Sutrisno, E. (2009) Komunikasi dalam organisasi. Jakarta: Kencana

Torang, S. (2014). Organisasi dan manajemen (perilaku, struktur, budaya dan perubahan organisasi). Bandung: Alfabeta. 